\title{
Dairy Herd-Level Prevalence of Johne's disease and BVD in the Intermountain West of the U.S.A. and Farm Management Practices and Characteristics for Test- Positive Herds
}

\author{
David J. Wilson ${ }^{\star}$, Kerry A. Rood, Chelsea Whitehouse, Jennifer Bunnell, Gregory M. Goodell and Todd M. Byrem \\ Department of Animal, Dairy and Veterinary Sciences, Utah State University, Logan, UT 84341 (Wilson, Rood, Whitehouse, Bunnell), The Dairy Authority, Greeley, CO \\ 80634 (Goodell), and Antel BioSystems, Lansing, MI 48909 (Byrem), USA
}

Rec date: June 26, 2015; Acc date: July 21, 2015; Pub date: July 23, 2015

*Corresponding author: David J. Wilson, Department of Animal, Dairy, and Veterinary Sciences, Utah State University, Utah Veterinary Diagnostic Laboratory, 950 East 1400 North, Logan, UT 84341, USA, Tel: (435) 760-3731; Fax: (435) 797-2805; E-mail: David.Wilson@usu.edu

Copyright: ( 2015 Wilson DJ, et al. This is an open-access article distributed under the terms of the Creative Commons Attribution License, which permits unrestricted use, distribution, and reproduction in any medium, provided the original author and source are credited.

\begin{abstract}
Herd-level prevalence of Mycobacterium avium subsp. paratuberculosis (MAP), causative agent of Johne's disease (JD) and Bovine Viral Diarrhea (BVD) virus were estimated on dairy farms in Utah. Duplicate milks were collected at 3-4 day intervals on 5 dates from each bulk tank on participating farms. Samples were tested at separate laboratories for BVD (real-time, RT-PCR) and for JD/MAP (ELISA and qPCR). 151/209 (72\%) eligible dairy farms participated. Farms detected positive were: $58 \mathrm{JD}(38 \%)$ and 14 BVD (9\%); 5 farms had both diseases. Follow up visited farms' ( $\mathrm{n}=22$ ) means, medians: 778,420 milking cows; 20,052 lbs, $20,311 \mathrm{lbs} 305 \mathrm{~d}$ milk; $175,545 / \mathrm{ml}$, $178,000 / \mathrm{ml}$ bulk milk SCC; stalls visibly soiled in rear one-third $37 \%, 32 \%$, range $5 \%$ to $90 \%$. Seventeen of $21(81 \%)$ farms with JD had observed adult cows becoming thin while retaining appetite, $52 \%$ had seen adult cows contract diarrhea and subsequently die. Both BVD-positive farms had observed abortions. Free stalls housed milking cows on $91 \%$ of farms; dry lots housed dry cows on $55 \%$. Nine farms $(41 \%)$ had purchased animals within the past year: $27 \%$ pregnant heifers, $18 \%$ bulls, $9 \%$ calves, $14 \%$ cows; $9 \%$ had purchased only bulls. Whenever animals were last purchased, 14 farms $(64 \%)$ had performed no disease testing or segregation; 8 farms (36\%) utilized at least one biosecurity practice for replacements. Most common were 9-way vaccine including BVD on arrival (27\%), 14\% segregated replacements for any time, $11 \%$ tested for any diseases (none for JD). Fourteen $(67 \%$ ) farms with JD would identify known positive cows; none would segregate positives. Most producers (57\%) allowed known JDpositive cows to calve again, farms with BVD were equivocal. No producers would have a separate calving area for JD or BVD-positive cows. Six farms (27\%) fed calves only individual cow colostrum and pasteurized milk. All 22 farms vaccinated against BVD.
\end{abstract}

Keywords: Johne's disease; BVD; Milk; Management; Epidemiology; Dairy cattle

\section{Introduction}

Johne's disease (JD, paratuberculosis) is an important chronic digestive tract disease of dairy cattle. Animals with JD may exhibit no clinical signs, or signs including weight loss, decreased milk production, intermittent or chronic diarrhea, emaciation, and death. Johne's disease is associated with increased risk of culling [1-6]. Mycobacterium avium subsp. paratuberculosis (MAP) is the etiologic agent of JD [2].

Estimated financial losses associated with JD range from \$250 million to $\$ 1.5$ billion annually in the U.S., possibly underestimated $[4,6]$. Loss estimates in JD-positive cows range from $\$ 83$ to $\$ 380$ per infected cow depending on parity/age, $\$ 77$ in increased culling losses per cow for all cows within a herd, and $\$ 49$ to $\$ 200$ per cow for all cows within infected herds [5,7-9].

Definitive data is lacking regarding the proportion of dairy herds infected with JD; estimates vary between different studies, countries and regions. Nevertheless, it is generally agreed that herd-level prevalence of JD has increased in developed countries, from approximately $10 \%$ to $30 \%$ of herds positive 20 to 25 years ago [10-12] to $38 \%$ to $74 \%$ of herds at present, with most regional estimates at approximately $43 \%$ of dairy herds positive for JD [13-15].

Bovine viral diarrhea (BVD) is another costly disease of ruminants, including dairy cattle $[9,16-19]$. A review in Denmark estimated that BVD losses ranged between $\$ 10$ and $\$ 40$ dollars per dairy cow calving [19]. Direct BVD costs were estimated in Canada, including premature culling, lost milk production, reduced slaughter value, abortion and reproductive loss, and mortality, estimated that mean annual costs were $\$ 48$ across all cows in an infected herd [9]. This was similar to estimated BVD losses among all cows in a U.S. study [18].

Cattle are infected with the BVD virus via transient, usually selfeliminating, episodes of viral transmission or from animals that were persistently infected (PI) during gestation. Animals infected with BVD in utero during the first few months of pregnancy, while fetal immunity is being developed, recognize the virus as "self". There is no resultant immune response, and the virus persists in these animals which are therefore born and remain PI. Large amounts of virus are shed by PI animals, and they represent the most likely reason that BVD circulates within herds [20]. While many PI animals eventually contract clinical signs of the disease, most of the clinical cases of BVD develop in cattle that are transiently infected. Effects of BVD infection include respiratory disease, gastrointestinal disease, immunosuppression, abortions, stillbirths, infertility, congenital defects, and lost meat and milk production [20]. 
Citation: Wilson DJ, Rood KA, Whitehouse C, Bunnell J, Goodell GM, et al. (2015) Dairy Herd-Level Prevalence of Johne's disease and BVD in the Intermountain West of the U.S.A. and Farm Management Practices and Characteristics for Test-Positive Herds. J Veterinar Sci Technol 6: 240. doi:10.4172/2157-7579.1000240

Page 2 of 7

There is reported worldwide distribution of BVD [21]. In the U.S., it is estimated that $0.13 \%$ of cows are PI [22]. Few studies have used PCR bulk milk sampling to estimate the percentage of herds with at least one PI, ranging from $15 \%$ in the U.S. [22] to $39 \%$ in Denmark [23].

Earlier surveillance projects of Utah and adjacent areas of the Intermountain West detected JD in 39\% of dairy herds in 2009 [24]. Statewide or regional surveillance of dairy herds for BVD had not been done. The objectives of the study reported here were estimation of the dairy herd-level prevalence of JD and BVD virus in Utah and the nearby Intermountain West using a repeated sampling scheme, and summarizing management practices and characteristics of farms with test-positive herds that participated in follow up farm visits.

\section{Materials and Methods}

\section{Study farms}

In order to sample bulk tank milk for testing for JD and BVD, written permission of dairy producers was obtained. Information and permission forms were distributed both electronically and personally by milk buying company field personnel to dairy producers in Utah and some producers from surrounding states that sold milk to either of the 2 major milk processors in Utah.

\section{Collection and handling of bulk tank milk samples}

Milk was collected from each bulk tank on participating farms at 3-4 day intervals on 5 sampling dates (duplicate samples each time) over approximately 15 days. Following agitation of milk for at least 5 min, milk haulers collected 2 extra samples into sterile vials at the same time they collected their routine testing samples. All samples were frozen at the processing plants at $-20^{\circ} \mathrm{C}$ and remained frozen until analysis. Using portable $-20^{\circ} \mathrm{C}$ freezers, all samples were transported to the Utah Veterinary Diagnostic Laboratory from the collection locations and then shipped frozen overnight by courier. One sample was sent to The Dairy Authority laboratory in Greeley, CO and the other sample collected on the same day was sent to Antel Bio Systems in Lansing, MI for testing.

\section{MAP detection in bulk tank milk samples}

At Antel Bio Systems all bulk tank samples were tested using 2 test methods as described previously [24,25]. Each bulk tank sample was analyzed for MAP-specific IgG antibody by a commercial ELISA (IDEXX Laboratories, Westbrook, ME) and for presence of MAP organism by quantitative real-time PCR (qPCR). ELISA scores above 0.1 optical density (OD) were considered positive for JD, resulting in test sensitivity and specificity of $52 \%$ and $94 \%$, respectively, when environmental fecal analysis was used as the "gold standard" for MAP detection $[25,26]$. Cycle threshold $(\mathrm{Ct})$ values below 41 were defined as positive PCR results for the presence of MAP. Sensitivity and specificity are $40 \%$ and $94 \%$, respectively, when compared to environmental fecal analysis for MAP detection $[25,26]$.

\section{BVD detection in bulk tank milk samples}

Screening of milk samples for BVD virus utilized a commercial BVD real-time reverse transcription PCR (Applied Bio systems, Carlsbad, CA) per manufacturer's instructions as previously reported [27-29].

\section{Case definitions and test sensitivity and specificity}

The specificity of milk testing for JD and BVD has been reported previously as nearly $100 \%$; false positive results are uncommon $[25,26,30]$. Therefore for each of the diseases JD or BVD, the finding of at least 1 positive test result for that disease in a herd was defined as a "true positive". Specificity (avoidance of false positives) was $100 \%$ by definition; no positive results were defined as "false positive".

Test sensitivity (avoidance of false negatives) was calculated for detection of each of the disease agents. Sensitivity was defined as the total number of positive test results for either agent divided by the total number of tests performed on all bulk milk samples from the herds defined as true positive for that agent. For example, if there were 284 JD-positive bulk tank samples among a total of 528 bulk tank samples from all farms that tested positive for JD/MAP, sensitivity $=284 / 528=54 \%$ for a single bulk tank sample test to detect JD/MAP.

\section{Confidentiality of results}

Investigators did not know the dairy producers' identities because farms were coded by number for anonymity by the 2 milk buyers. Owners of herds positive for either of the diseases were contacted through the milk buyer field personnel using their number code; their identities were revealed to the investigators if the producers agreed. Those producers were contacted for a follow up program including possible farm visits.

\section{Farm follow up questionnaire}

Two of the investigators (DW, KR) modified a questionnaire that they had developed and used during previous surveillance and outreach projects, designed to evaluate farm management practices and characteristics associated with JD and BVD. Initially, 6 farm visits were made by all 4 field investigators (DW, KR, CW, and JB) together to standardize observations and interview methods. The remaining farm visits were made in pairs $(\mathrm{DW} / \mathrm{CW}, \mathrm{KR} / \mathrm{JB}$, or $\mathrm{CW} / \mathrm{JB})$ or singly by DW or KR. Surveillance results were compiled and analyzed using a data management program (Microsoft Excel, Bellevue, WA).

\section{Results}

\section{Sample collection}

Signed forms authorizing milk sample collection and testing were returned by $151 / 209$ (72\%) of the dairy producers in the study area of Utah and adjacent areas of the Intermountain West. There were 179 bulk tanks on the 151 participating dairy farms, from which 1,822 bulk tank milk samples (911 pairs) were collected, sampled 3-4 days apart. Samples were maintained frozen at $-20^{\circ} \mathrm{C}$ as described earlier and arrived frozen at both testing laboratories.

\section{Number of dairy herds testing positive for at least one disease}

There were 67 herds (44\%) that tested positive for either JD or BVD; 62 herds were positive for one of the diseases and 5 herds were positive for both diseases. The remaining 84 herds (56\%) tested negative for JD and BVD. 
Citation: Wilson DJ, Rood KA, Whitehouse C, Bunnell J, Goodell GM, et al. (2015) Dairy Herd-Level Prevalence of Johne's disease and BVD in the Intermountain West of the U.S.A. and Farm Management Practices and Characteristics for Test-Positive Herds. J Veterinar Sci Technol 6: 240. doi:10.4172/2157-7579.1000240

Page 3 of 7

\section{Herd-level prevalence of JD}

Bulk tank milk tested positive for JD at least once from 58/151 dairy herds $(38 \%)$ in the study area. Five of these herds were also positive for BVD. Among the JD-positive herds, the proportion of their bulk tank samples that tested positive ranged from 100\% (19 herds) to 5\% (one herd). Median proportion of bulk tanks testing JD-positive among all positive herds was $3 / 5(60 \%)$. The farm with the largest number of bulk tank samples collected (38 samples) showed how variable the shedding of MAP can be; that farm had 3 bulk tanks, all with milk picked up twice every day, sometimes 3 times within $24 \mathrm{~h}$. For all $6 \mathrm{JD}$ positive tank results on that farm - only 2 of the 3 tanks on the farm were ever positive - milk from the same tanks was JD-negative when collected approximately 12 hours earlier or later on the same day.

\section{Herd-level prevalence of BVD}

Bulk tank milk tested positive for BVD at least once from 14/151 herds (9\%), including the 5 that also were JD-positive. The proportion of their bulk tanks testing BVD-positive ranged from $100 \%$ (3 herds) to $6 \%$ (one herd). The median proportion of their bulk tanks testing BVD-positive was $1 / 4(25 \%)$.

\section{Bulk tank test sensitivity}

Test sensitivity for JD detection was calculated by dividing the total number of JD-positive bulk tank results by the total number of bulk tank milk samples tested from the JD-positive farms. There were 284 JD-positive bulk tank samples among the 528 bulk tank samples from the 58 positive farms; therefore $284 / 528=54 \%$ sensitivity of a single bulk tank sample test for detection of JD. Similarly, sensitivity of a single sample for detection was $41 / 117=35 \%$ for BVD.

\section{Descriptive statistics and farm facilities of herds positive for JD and/or BVD}

One of the milk buying companies did not cooperate with the follow up program; they did not reveal any identities of producers with positive herds to the investigators as previously agreed upon. Of the test-positive herd owners who shipped milk to the other milk processor, 22 agreed to follow up farm visits.

On the 22 farms visited, personnel interviewed included at least one owner and usually the herdsperson as well, sometimes the herd health veterinarian and other farm employees, and observations were made to complete the questionnaire; 20 herds were JD-positive only, one was BVD-positive only, and one was positive for both diseases. Mean and median lactating herd size were 778 cows and 420 cows, respectively, ranging from 52 to 6523 cows. Mean and median $305 \mathrm{~d}$ milk productions were $20,052 \mathrm{lbs}(9240 \mathrm{~kg})$ and $20,311 \mathrm{lbs}(9221 \mathrm{~kg})$, respectively, ranging from $14,918 \mathrm{lbs}(6773 \mathrm{~kg})$ to $25,350 \mathrm{lbs}(11,509$ $\mathrm{kg}$ ). Mean and median somatic cell count (SCC) in bulk tank milk (from all milk plant records available over the previous 6 months) were $175,545 / \mathrm{ml}$ and $178,000 / \mathrm{ml}$, respectively, ranging from $94,000 / \mathrm{ml}$ to $300,000 / \mathrm{ml}$.

Holsteins were the major breed on 21 farms (95\%), Jerseys were the major breed on one farm (5\%), but 15 of the 22 farms (68\%) had a mixture of Holsteins with Jerseys $(n=12$ farms), Brown Swiss $(n=7)$, Norwegian Red $(\mathrm{n}=2)$, and one farm also had Ayrshires and Montbeliardes.
All 22 farms milked cows in parlors: 15 farms (68\%) had herringbone parlors, 6 farms (27\%) had parallel parlors, and one farm (5\%) had a rotary parlor. Mean and median number of milking units was 28 units and 22 units, respectively, ranging from 6 to 160 units. Most farms ( $\mathrm{n}=13)$ had 12 to 24 units, all in double sided (not rotary or single-sided) parlors. Except for the farm with 160 units in a parallel parlor, no other farm had more than 40 units. The rotary parlor had 32 units. Variable frequency drive vacuum pumps were used on 16 farms (73\%).

Primary lactating cow housing was outdoor free stalls with small roofs above on 16 farms (73\%), free stalls in covered barns on 4 farms (18\%), and dry lot on 2 farms (9\%). Four of the free stall operations also had some dry lot housing (one also had some pasture as well), and 3 had some loose housing. The primary dry cow housing was dry lot on 12 farms (55\%), free stalls in covered barns on 4 farms (18\%) (none were the same 4 farms that had that type of lactating cow housing), outdoor free stalls with small roofs above on 3 farms (14\%), loose housing on 2 farms (9\%), and pasture on one farm (5\%). Six of the dry lot operations also had some loose housing (one also had some pasture as well) for dry cows; 2 of the free stall farms also had dry lot housing, one had some loose housing, and one had an exercise lot for dry cows.

On the 20 farms with lactating cow free stall housing, at least 20 stalls in each row in each pen were observed and the percentage of stalls with visible manure or urine in the back one-third of the stall was calculated. Usually at least 40 stalls per pen were graded in this way. The goal is $5 \%$ or fewer visibly soiled stalls. Mean and median percentages of stalls visibly soiled in the back one-third were $37 \%$ and $32 \%$, respectively, ranging from $5 \%$ to $90 \%$. One farm reached the goal of $5 \%$ soiled stalls, and 2 farms had $90 \%$ soiled, one of which was the farm detected with BVD and JD.

Bedding used in free stalls ( $\mathrm{n}=20$ farms) had an unexpected association with percentage of soiled stalls (this observational finding was not tested statistically because it was not a planned experiment), which was not consistent with the experience of the authors. There was one farm (5\%) bedding with sawdust that had 5\% soiled stalls; 3 farms (15\%) bedding with sand had $15 \%, 15 \%$ and $30 \%$ soiled stalls. The 16 farms $(80 \%)$ that bedded with straw (2 also mixed in recycled manure, one also used mats, one also use water beds) had mean and median of $43 \%$ and $44 \%$ soiled stalls, respectively, ranging from $10 \%$ (the farm that also used water beds under the straw) to $90 \%$. Eight of the 16 farms bedding with straw had $50 \%$ to $90 \%$ of stalls with visible manure or urine in the back one-third.

Free stall maintenance was evaluated based upon stall width 44 " $(112 \mathrm{~cm})$ to $50 "(127 \mathrm{~cm})$, stall dividers firmly in place rather than loose, broken or absent, and position of brisket (held by neck rail or brisket board) 5' 4" $(163 \mathrm{~cm})$ to $5^{\prime} 10^{\prime \prime}(178 \mathrm{~cm})$ from the back edge of the stall. All 20 farms had stall dimensions within standards; therefore the de facto indicator of stall maintenance was whether stall dividers were firmly in place rather than loose, broken or absent. One or two poor stall dividers were considered acceptable. If multiple poor stall dividers were observed in multiple areas of the cow housing, this was defined as poor free stall maintenance. Stalls were well maintained on $15(75 \%)$ of farms, and poorly maintained on 5 (25\%) of the farms with free stalls. Farms with well-maintained stalls had mean and median of $31 \%$ and $30 \%$ soiled stalls, respectively; farms with poorly maintained stalls had $50 \%$ ( $\mathrm{n}=4$ farms) and $90 \%$ (one farm) of stalls with visible manure or urine in the back one-third. 
Citation: Wilson DJ, Rood KA, Whitehouse C, Bunnell J, Goodell GM, et al. (2015) Dairy Herd-Level Prevalence of Johne's disease and BVD in the Intermountain West of the U.S.A. and Farm Management Practices and Characteristics for Test-Positive Herds. J Veterinar Sci Technol 6: 240. doi:10.4172/2157-7579.1000240

Page 4 of 7

\section{Biosecurity and herd replacement practices}

Thirteen (59\%) of the farms, 12 with JD only and the one with BVD only, had been closed for at least one year to any purchased animals, including pregnant replacement heifers, bulls or calves as well as cows, for a mean of 4 years, median of 5 years, ranging from 1.5 to 7 years. The other 9 farms (41\%), including 8 with JD only and the one with BVD and JD, had purchased animals within the past year. Six farms (27\% of all farms) had purchased pregnant replacement heifers, 4 farms (18\%) had purchased bulls, 2 farms (9\%) had purchased calves, and 3 farms (14\%) had purchased cows within the past year. Most farms had purchased multiple categories of animals, but one farm had purchased only calves, and 2 farms had purchased only bulls.

Whether or not the farms were closed to purchase animals, the owners were asked about biosecurity practices whenever animals were last purchased. Fourteen farms (64\%) had performed no disease testing, segregation or any biosecurity practices when buying replacement animals (this included 10 of the 13 with closed herds, and 4 of the 9 farms that had purchased animals during the previous year). One of the open farms with no biosecurity practices was the farm with both BVD and JD detected in the herd. The other 8 farms $(36 \%)$ utilized at least one biosecurity practice the last time they purchased animals: the 3 closed farms had all used IBR-BVD-PI3-BRSV-Lepto 5way vaccine (9-way vaccine) on arrival, and 2 of those farms had also used segregation of new additions for an unspecified amount of time, and were currently furnishing plastic boots to any farm visitors who did not bring their own disinfected boots; the 5 open farms included 3 that used 9-way vaccine on arrival, one of which also cleaned livestock trailers after unloading the replacement animals, one farm that tested replacements for BVD (antigen capture ear notch ELISA) [17] and tuberculosis (caudal fold tuberculin test), and one farm that tested replacements for BVD (antigen capture ear notch ELISA), Mycoplasma spp. (accepted mycoplasma culture methods) [31], and segregated new additions for an unspecified amount of time.

Independent of testing replacement animals, producers were asked whether they had ever previously tested their herds for JD or BVD. Eleven $(50 \%)$ of the farms answered that they had tested for JD, primarily by occasionally testing individual cows with clinical signs of the disease; these included 5 with closed herds and 6 farms that had purchased replacements during the previous year. None of the farms had tested the whole herd on any regular basis for JD. The remaining 11 farms (50\%) could recall no previous testing for JD, including 8 with closed herds and 3 with open herds. None of the producers had tested the entire herd or tested part of the herd on a regular basis for BVD; some had tested some animals periodically for PI status, but details of their previous BVD testing programs were not clear, and records were not found. Among the farms having done no previous testing for either disease were the farm that was positive only for BVD and the farm with both JD and BVD detected.

Sixteen $(73 \%)$ of the 22 farms had had at least one previous positive test for JD before the current surveillance project. This included 7 of the 11 farms that could recall no previous JD testing, but they had participated in an earlier statewide JD surveillance project with one of the authors (DW), and had been test-positive in bulk tank milk for JD. They had been informed of the previous positive results, but this had not persuaded the owners to perform any additional JD testing. Of the 11 farms that had performed JD testing on some cows, 9 had at least one previous positive result.

\section{Segregation or identification of known JD-positive cows}

Producers were asked about the possibility of segregating all known JD-positive cows; none said they would segregate. Five (24\%) of the 21 farms detected with JD would not segregate, and the remaining 16 (76\%) producers were not sure. When asked regarding adopting some form of identification of known JD-positive cows, 14 (67\%) of the 21 producers whose herds were detected with JD said they would identify the positive cows.

\section{Calving practices}

Producers were asked whether known JD-positive cows, or when applicable, BVD-positive cows would be allowed to calve again on the farm, and if they were allowed to calve again, whether known JDpositive cows, or when applicable, BVD-positive cows, would calve in a different area than test-negative cows. Twelve (57\%) of the $21 \mathrm{farms}$ that were detected positive for JD would allow JD-positive cows to calve again on the farm, including 9 of the 16 that had had at least one positive test for JD, and 3 of the 5 that had never had any positive JD results before the current surveillance project. Six (29\%) producers answered that they would not let any known JD-positive cows calve again on the farm, 5 that had had some positive results previously, and one that had tested individual cows but never had any positive results before the current project. Three (14\%) answered that they were not sure whether they would let known JD-positive cows calve again on the farm, 2 with some previous positive results, and one that had never tested for JD before the current project. Both producers whose herds were detected BVD-positive said that whether BVD-positive cows would calve again on the farm would depend on how many there were; if "only a few PI's" were found, they would all be culled right away. The farm with both JD and BVD was one of those described above that would allow JD-positive cows to calve again on the farm.

No producers who would allow JD-positive or BVD-positive cows to calve again on the farm said that such cows would have a separate calving area. All 12 who said that positive cows would calve again (including the farm with both JD and BVD) said they would calve in the same calving area as other cows and all 4 who were not sure about allowing positive cows to calve again also said they were not sure regarding a separate calving area.

\section{Calf feeding procedures}

Calves were fed pooled (mixed from $>1$ cow) colostrum on 14 (64\%) farms, including both farms detected BVD-positive. Of the remaining 8 farms that fed only colostrum from individual cows, 6 (75\%) also pasteurized all discard milk fed to calves. Only 2 (14\%) of the 14 farms feeding pooled colostrum also pasteurized their discard milk fed to calves. Thus 12 farms (55\%) fed both pooled colostrum and unpasteurized discard milk to calves.

\section{BVD vaccination, manure handling, and clinical signs observed}

All 22 farms used 9-way vaccine which included BVD vaccine (some killed, some modified live, some farms used a combination of both at different times). Six (27\%) farms used machinery to move manure and also to handle feed; 3 (50\%) of them did not wash machinery after contacting manure and before the next contact with feed. Of the 21 farms detected with JD, 17 (81\%) had observed adult cows becoming thin while maintaining a good appetite; $11(52 \%)$ had 
Citation: Wilson DJ, Rood KA, Whitehouse C, Bunnell J, Goodell GM, et al. (2015) Dairy Herd-Level Prevalence of Johne's disease and BVD in the Intermountain West of the U.S.A. and Farm Management Practices and Characteristics for Test-Positive Herds. J Veterinar Sci Technol 6: 240. doi:10.4172/2157-7579.1000240

Page 5 of 7

seen adult cows contract diarrhea and subsequently die. Both BVDpositive farms had observed abortions. The farm that was positive only for BVD had 30 sheep of all ages mixed with dairy animals. The sheep were not vaccinated against BVD.

\section{Milking practices}

While milking practices are not considered strongly related to JD or BVD, they are always important and interesting management practices on dairy farms. All farms used udder preparation and teat disinfection before milking, and post milking teat dipping as well. Predip was used on 21 farms (95\%); the remaining farm used an udder wash of iodine in water. The predip germicides and methods of application were: 4 farms (18\%) used $0.15 \%$ iodine ( 3 foamers, one cup); 3 farms (14\%) used $0.25 \%$ iodine spray; 6 farms $(27 \%)$ used $0.5 \%$ iodine ( 3 cup, 3 spray); 4 farms (18\%) used 1\% iodine ( 2 cup, 2 spray); 3 farms (14\%) used $3 \%$ hydrogen peroxide (one foamer, one cup, one spray), one farm (5\%) used sodium chlorite lactic acid (SCLA), cup. The postdip germicides and methods of application were: one farm (5\%) used $0.15 \%$ iodine, cup (same as their predip); 3 farms (14\%) used $0.25 \%$ iodine spray (same as their predip); 2 farms (9\%) used $0.5 \%$ iodine spray (same as their predip); 14 farms (64\%) used $1 \%$ iodine (11 cup, 3 spray) ( 2 of the cup and 2 of the spray farms, same as their predip); 2 farms (9\%) used SCLA, cup (for one farm it was the same as their predip).

On the 16 farms where milking was observed, evaluation was made regarding whether teats were covered with predip well, fair or poor according to a visual scale standardized among the 4 investigators (the udder wash farm was one where milking was not observed). Teats were covered with predip well on 12 farms (75\%) and fair on 4 farms (25\%). Three of the 4 farms with only fair teat dip coverage spray dipped, but one farm cup dipped. A common (used on multiple cows) cloth $(n=8)$ or common paper towel $(n=4)$ was used to wipe off teats following disinfection on 12 (55\%) of farms; the other 10 farms (45\%) used an individual-cow cloth $(\mathrm{n}=8)$ or paper towel $(\mathrm{n}=2)$. On 18 farms, there was sufficient information available to calculate turns of the milking parlor per hour. Mean and median turns/hour were 3.8 and 3.7, respectively, ranging from 2 to 5.9 /hour. Four of the 6 farms with $<3$ turns/hour had 12 to 18 milking units, and 4 of the 6 farms with $>4$ turns/hour had 32 to 160 milking units.

Rubber inflations (teat cup liners) were used on 17 farms (77\%) and silicone inflations were used on 5 farms (23\%). Frequency of changing inflations was known by the managers of 16 farms (13 using rubber, 3 using silicone), therefore the number of individual cow milking's (ICM) for which inflations were used could be calculated. For rubber inflations, mean and median ICM of use were 1867 and 1710, respectively, ranging from 660 to 3119 ICM. The upper limit of recommended use for rubber inflations is 1200 ICM [32], so 11 of the 13 farms (85\%) overused rubber inflations. For silicone inflations, the 3 farms used them for 2835, 3982 and 9000 ICM. The upper limit of recommended use for silicone inflations is 7000 ICM, therefore one of the 3 farms (33\%) overused silicone inflations.

\section{Lactating and dry cow treatments for mastitis}

Lactating cows with clinical signs of mastitis were treated with intramammary antibiotics on 20 (91\%) farms. The most commonly used antibiotics for lactating cows were: ceftiofur, 10 farms (50\%); cephapirin, 4 farms (20\%); pirlimycin, 3 farms (15\%); amoxicillin, 2 farms (10\%); ampicillin, one farm (5\%). One farm (the only organic dairy) used no treatment for mastitis cases, and one farm used I.M. oxytocin only. Five of the above farms that routinely used antibiotics sometimes treated clinical mastitis cases with I.M. oxytocin as the only treatment. None of the farms treated clinical mastitis cases with antiinflammatory therapy.

Dry cow therapy - intramammary infusion of long-acting, slow release antibiotics at the beginning of the non-lactating period - was administered to all cows when they were dried off on 20 (91\%) farms. The most commonly used dry cow antibiotics were: cephapirin, 6 farms (30\%); penicillin and novobiocin, 6 farms (30\%); ceftiofur, 5 farms (25\%); penicillin-dihydrostreptomycin, 2 farms (10\%); cloxacillin, one farm (5\%). The organic farm used a wax and oil teat sealant on selected cows, but no dry treatment on most cows, and one farm used no dry treatment of any kind because of fear of adulteration of milk. Seven farms (32\%), all of which also used antibiotic dry cow therapy, used a teat sealant following dry cow treatment.

\section{Feeding monensin}

The 21 producers with JD detected in their herds were asked regarding feeding of the ionophore monensin to different age groups of dairy animals. Monensin has been reported as a chemoprophylactic agent associated with reduction of the new infection rate, decreased inflammation within affected tissues, and reduced prevalence of milkpositive cows and fecal-positive calves with JD [33]. Seventeen (81\%) farms fed monensin: 10 (48\%) fed mature cows, 9 (43\%) fed first lactation cows, 14 (67\%) fed breeding age heifers and 7 (33\%) fed calves monensin.

\section{Other management practices}

Tail docking was practiced on $12(55 \%)$ of farms; neither of the BVD-positive farms docked tails. Coliform mastitis vaccine using J5 antigen was administered to cows on 19 (86\%) of farms, including both farms with herds detected BVD-positive.

\section{Discussion}

Mean herd size and milk production of JD and BVD-positive herds were both above Utah average, and SCC/ml in bulk tank milk was below (better than) average. Many herds test-positive for JD or BVD had been closed to any outside animals for years. Biosecurity measures on most farms, whether they had purchased animals recently or not, were lacking; most producers did not test for BVD or JD (or most other diseases) when purchasing replacement animals of any age or sex into their herds, or even segregate new additions for any time before mixing them into the resident herd. This continues a longstanding pattern of dairy producers poorly adopting recommended screening or quarantine practices when adding replacements to their herds $[15,34]$.

The majority of farms had observed clinical signs typically associated with JD or sometimes BVD such as adult cows developing diarrhea progressing to death, and nearly all had seen cows losing weight and becoming thin while maintaining a good appetite $[2,6,19,21]$. Previously positive tests for JD or BVD, either in bulk tank milk or on occasional individual animals, did not induce most producers to do further individual testing or institute specific control measures.

While two-thirds of producers stated that they would uniquely identify known JD-positive cows, none were willing to segregate the 
Citation: Wilson DJ, Rood KA, Whitehouse C, Bunnell J, Goodell GM, et al. (2015) Dairy Herd-Level Prevalence of Johne's disease and BVD in the Intermountain West of the U.S.A. and Farm Management Practices and Characteristics for Test-Positive Herds. J Veterinar Sci Technol 6: 240. doi:10.4172/2157-7579.1000240

Page 6 of 7

positive cows. The majority of producers would allow known JDpositive cows to calve again on their farms, and producers with BVD detected in their herds were equivocal. No producers would have a separate calving area for JD or BVD-positive cows either. This was despite previous information and recommendations regarding the importance of separate calving areas for and preferably isolation of JDpositive cows to reduce the spread of the disease within dairy herds $[1,15]$. It is often recommended that BVD-positive cows (in the U.S. those detected are nearly all PI animals) be culled $(19,20)$, but economic studies do not conclusively find this to be cost-effective, including the practice of culling PI animals [19,21]. In this study, producers were not committed to culling BVD-positive cows.

Of the one-fourth of producers who used the same equipment to move manure and handle feed, half would not wash the equipment between contact with the manure and feed. Most farms fed both pooled colostrum and unpasteurized discard milk to calves, while less than one-third of farms fed only individual-cow colostrum and only pasteurized milk to calves. These practices were in place regardless of the evidence and recommendations within the industry that the above control measures help reduce the likelihood of calves contracting JD [14].

One farm positive for BVD had sheep of all ages mixed with the dairy cattle. The sheep were not vaccinated against BVD. It is common for sheep to be infected with BVD virus, and although considered an unusual route, they can be infectious to cattle, including being associated with the birth of PI calves [35].

While not directly related to JD or BVD, it was of interest that $85 \%$ of farms overused rubber inflations (teat cup liners), and one-third overused silicone inflations. Inflations are the only part of the milking system that touches cows, and an important source of some kinds of new intramammary infections and teat end irritation [36]. Nevertheless, it has been the experience of the authors (DW, GG) for over 25 years that one of the most common categories of inadequate maintenance of milking systems on most dairy farms is overuse of inflations.

Many recommended control measures for prevention of introduction and/or to reduce the new infection rate of JD or BVD were poorly adopted. Most farms in the study had previous diagnostic evidence of the presence of JD in their dairy herds, whether from bulk tank milk or individual cow testing and all had recently been informed through their participation in a voluntary surveillance project that they had tested positive for JD or BVD. This continues a decades-old pattern of general apathy by many producers regarding attempted elimination or reduction of the prevalence of JD or BVD, or even elimination of only the clinical JD cases and/or only the PI BVD cattle from their herds. Dairy producers often respond that they think control measures for JD, BVD or other diseases recommended to them by veterinarians and other herd health advisors make sense, including financial sense, and would be beneficial, but they either find them unimportant, impractical, or inconvenient $[35,37,38]$.

\section{Acknowledgements}

This work was funded by grants from Utah State University, Federal Formula Animal Health Funds, Utah Agricultural Experiment Station, and Utah State University Extension Grants. We appreciate the cooperation of the owners of the participating dairy farms and the milk buyer personnel who recruited the participants and collected the milk samples.

\section{References}

1. Wilson DJ, Rossiter C, Han HR, Sears PM (1993) Association of Mycobacterium paratuberculosis infection with reduced mastitis, but with decreased milk production and increased cull rate in clinically normal dairy cows. Am J Vet Res 54: 1851-1857.

2. Stabel JR (1998) Johne's disease: a hidden threat. J Dairy Sci 81: 283-288.

3. Tiwari A, VanLeeuwen JA, Dohoo IR, Stryhn H, Keefe GP, et al. (2005) Effects of seropositivity for bovine leukemia virus, bovine viral diarrhoea virus, Mycobacterium avium subspecies paratuberculosis, and Neospora caninum on culling in dairy cattle in four Canadian provinces. Vet Microbiol 109: 147-158.

4. Clark DL, Koziczowski JJ, Radcliff RP, Carlson RA, Ellingson JL (2008) Detection of Mycobacterium avium subspecies paratuberculosis: comparing fecal culture versus serum enzyme-linked immunosorbent assay and direct fecal polymerase chain reaction. J Dairy Sci 91: 2620-2627.

5. Tiwari A, VanLeeuwen JA, Dohoo IR, Keefe GP, Weersink A (2008) Estimate of the direct production losses in Canadian dairy herds with subclinical Mycobacterium avium subspecies paratuberculosis infection. Can Vet J 49: 569-576.

6. Salem M, Heydel C, El-Sayed A, Ahmed SA, Zschöck M, et al. (2013) Mycobacterium avium subspecies paratuberculosis: an insidious problem for the ruminant industry. Trop Anim Health Prod 45: 351-366.

7. Wilson DJ, Rossiter CM, Han HR, Sears PM (1995) Financial effects of Mycobacterium paratuberculosis on mastitis, milk production and cull rate in clinically normal cows. Agri Pract 16: 12-18.

8. Ott SL, Wells SJ, Wagner BA (1999) Herd-level economic losses associated with Johne's disease on US dairy operations. Prev Vet Med 40: 179-192.

9. Chi J, VanLeeuwen JA, Weersink A, Keefe GP (2002) Direct production losses and treatment costs from bovine viral diarrhoea virus, bovine leukosis virus, Mycobacterium avium subspecies paratuberculosis, and Neospora caninum. Prev Vet Med 55: 137-153.

10. Merkal RS, Whipple DL, Sacks JM, Snyder GR (1987) Prevalence of Mycobacterium paratuberculosis in ileocecal lymph nodes of cattle culled in the United States. J Am Vet Med Assoc 190: 676-680.

11. Collins MT, Sockett DC, Goodger WJ, Conrad TA, Thomas CB, et al. (1994) Herd prevalence and geographic distribution of, and risk factors for, bovine paratuberculosis in Wisconsin. J Am Vet Med Assoc 204: 636-641.

12. Sockett DC (1996) Johne's disease eradication and control: Regulatory implications: The Veterinary clinics of North America. Food animal practice 12: 431-440.

13. Tiwari A, VanLeeuwen JA, McKenna SL, Keefe GP, Barkema HW (2006) Johne's disease in Canada Part I: clinical symptoms, pathophysiology, diagnosis, and prevalence in dairy herds. Can Vet J 47: 874-882.

14. Tavornpanich S, Johnson WO, Anderson RJ, Gardner IA (2008) Herd characteristics and management practices associated with seroprevalence of Mycobacterium avium subsp paratuberculosis infection in dairy herds. Am J Vet Res 69: 904-911.

15. Sorge US, Lissemore K, Godkin A, Jansen J, Hendrick S, et al. (2011) Changes in management practices and apparent prevalence on Canadian dairy farms participating in a voluntary risk assessment-based Johne's disease control program. J Dairy Sci 94: 5227-5237.

16. Dubovi EJ (1994) Impact of bovine viral diarrhea virus on reproductive performance in cattle: The Veterinary clinics of North America. Food animal 10: 503-514.

17. Hessman BE, Fulton RW, Sjeklocha DB, Murphy TA, Ridpath JF, et al. (2009) Evaluation of economic effects and the health and performance of the general cattle population after exposure to cattle persistently infected with bovine viral diarrhea virus in a starter feedlot. Am J Vet Res 70: 73-85.

18. Houe H (1999) Epidemiological features and economical importance of bovine virus diarrhoea virus (BVDV) infections. Vet Microbiol 64: 89-107. 
Citation: Wilson DJ, Rood KA, Whitehouse C, Bunnell J, Goodell GM, et al. (2015) Dairy Herd-Level Prevalence of Johne's disease and BVD in the Intermountain West of the U.S.A. and Farm Management Practices and Characteristics for Test-Positive Herds. J Veterinar Sci Technol 6: 240. doi:10.4172/2157-7579.1000240

Page 7 of 7

19. Houe $\mathrm{H}$ (2003) Economic impact of BVDV infection in dairies. Biologicals 31: 137-143.

20. Lanyon SR, Hill F, Reichel MP, Brownlie J (2014) Bovine viral diarrhoea: pathogenesis and diagnosis. Vet J 199: 201-209.

21. Houe H (1995) Epidemiology of bovine viral diarrhea virus: The Veterinary clinics of North America. Food animal practice 11: 521-547.

22. Houe H, Baker JC, Maes RK, Wuryastuti H, Wasito R, et al. (1995) Prevalence of cattle persistently infected with bovine viral diarrhea virus in 20 dairy herds in two counties in central Michigan and comparison of prevalence of antibody-positive cattle among herds with different infection and vaccination status. J Vet Diagn Invest 7: 321-326.

23. Bitsch V, Rønsholt L (1995) Control of bovine viral diarrhea virus infection without application of vaccines: The Veterinary clinics of North America. Food animal practice 11: 627-640.

24. Wilson DJ, Rood K, Biswas P, Byrem TM (2010) Herd-level prevalence of Johne's disease in Utah and adjacent areas of the Intermountain West as detected by a bulk tank milk surveillance project. J Dairy Sci 93: 5792-5797.

25. Biswas PW, Foshaug H, Donohue H, Lombard J, Byrem T (2008) Bulk milk testing for Johne's disease detection at the farm level. Proceedings of the Fourth Annual Conference of the Johne's Disease Integrated Program (JDIP): 27.

26. Lombard JE, Wagner BA, Smith RL, McCluskey BJ, Harris BN, et al. (2006) Evaluation of environmental sampling and culture to determine Mycobacterium avium subspecies paratuberculosis distribution and herd infection status on US dairy operations. J Dairy Sci 89: 4163-4171.

27. Bhudevi B, Weinstock D (2001) Fluorogenic RT-PCR assay (TaqMan) for detection and classification of bovine viral diarrhea virus. Vet Microbiol 83: 1-10.

28. Chirgwin JM, Przybyla AE, MacDonald RJ, Rutter WJ (1979) Isolation of biologically active ribonucleic acid from sources enriched in ribonuclease. Biochemistry 18: 5294-5299.
29. Chomczynski P, Sacchi N (1987) Single-step method of RNA isolation by acid guanidinium thiocyanate-phenol-chloroform extraction. Anal Biochem 162: 156-159.

30. Kim SG, Dubovi EJ (2003) A novel simple one-step single-tube RTduplex PCR method with an internal control for detection of bovine viral diarrhoea virus in bulk milk, blood, and follicular fluid samples. Biologicals 31: 103-106.

31. Maunsell FP, Woolums AR, Francoz D, Rosenbush RF, Step DL, et al. (2011) Mycoplasma bovis infections in cattle. J Vet Intern Med 4: 772-783.

32. Davis MA, Reinemann DJ (2000) Effect of liner age on milking characteristics of the liner. Proceedings of the Second International Symposium on Mastitis and Milk Quality: 444.

33. Fecteau ME, Whitlock RH (2011) Treatment and chemoprophylaxis for paratuberculosis. Vet Clin North Am Food Anim Pract 27: 547-557.

34. Maunsell F, Donovan GA (2008) Biosecurity and risk management for dairy replacements. Vet Clin North Am Food Anim Pract 24: 155-190.

35. Graham DA, Clegg TA, Lynch M, More SJ (2013) Herd-level factors associated with the presence of bovine viral diarrhoea virus in herds participating in the voluntary phase of the Irish national eradication programme. Prev Vet Med 112: 99-108.

36. Mein GA (2012) The role of the milking machine in mastitis control: The Veterinary clinics of North America. Food animal practice 28: 307-320.

37. Sorge U, Kelton D, Lissemore K, Godkin A, Hendrick S, et al. (2010) Attitudes of Canadian dairy farmers toward a voluntary Johne's disease control program. J Dairy Sci 93: 1491-1499.

38. Ridpath J (2012) Preventive strategy for BVDV infection in North America. Jpn J Vet Res 60: 41-49. 